\title{
Phytoplankton composition and selective feeding of the pearl oyster Pinctada margaritifera in the Takapoto lagoon (Tuamotu Archipelago, French Polynesia): in situ study using optical microscopy and HPLC pigment analysis
}

\author{
Pascale Loret $^{1, *}$, Annie Pastoureaud ${ }^{2}$, Cédric Bacher ${ }^{2}$, Bruno Delesalle $^{1}$ \\ 'EPHE, URA-CNRS 1453, Université de Perpignan, 66860 Perpignan Cédex, France \\ ${ }^{2}$ CREMA, BP 5, 17137 L'Houmeau, France
}

\begin{abstract}
The in situ diet of the pearl oyster Pinctada margaritifera was determined in the lagoon of Takapoto Atoll by comparing the phytoplankton composition of water and bivalve gut contents using 2 different methods, optical microscopy and HPLC pigment analysis. In order to evaluate the available food resources for pearl oysters in the water column, a new method for estimating the pigment/chlorophyll a (chl a) ratio (based on an inverse analysis) was developed which allowed us to determine the contribution of the main phytoplanktonic groups in terms of chl $a$. In the water, picocyanobacteria and nanoflagellates predominated, the latter being mainly chlorophytes and prymnesiophytes. Comparisons between the results obtained by the 2 methods of investigation indicated that most of the dinoflagellates are unpigmented and, therefore, heterotrophic. An examination of the gut contents showed that picocyanobacteria were only weakly ingested by the oyster and, thus, nanoflagellates constituted the main food resource. Cryptophytes, although poorly represented in the water, were preferentially ingested. Chlorophytes were inefficiently digested since they were found alive and motile in the faeces of the oyster. The ecological implications of this feeding behaviour are discussed.
\end{abstract}

KEY WORDS: Pearl oyster Pinctada margaritifera - Selective feeding · Natural diet - Phytoplankton pigments · Coral reefs · French Polynesia

\section{INTRODUCTION}

The question of how much food must be available to sustain a given population is frequently raised in the mariculture of filter-feeders. Food resources are generally considered as a limiting factor required for achieving high density rearings (Grant 1996, Rheault \& Rice 1996). Many studies have been carried out on bivalve shellfish in temperate areas and used to establish predictive models of trophic capacity for rearing zones (e.g. Bacher 1989, Raillard \& Menesguen 1994, Campbell \& Newell 1998, Grant \& Bacher 1998). Moreover,

•E-mail: loret@univ-perp.fr the impact of mariculture on modifications of the ecosystems has already been investigated and concerned either the nutrient cycling (Kautsky \& Evans 1987, Dame 1993, Herman 1993, Smaal \& Prins 1993) or the grazing pressure (Gerritsen et al. 1994, Baker et al. 1998, Makarewicz et al. 1999). In contrast, few studies have been undertaken in tropical environments (Hawkins et al. 1998).

Even though the production of black pearls constitutes the main economic resource of French Polynesia, the mariculture of the mother-of-pearl Pinctada margaritifera (Linné, 1758) has been, for a long time, based on an empirical knowledge of this bivalve and its natural environment. The mortality, which occurred in 1985 and affected pearl oysters rearings in the Taka- 
poto lagoon, demonstrated the lack of precise knowledge on this bivalve. It induced the development of a multidisciplinary research program on pearl oyster (Programme Général de Recherche sur la Nacre [PGRN]). Assessing the carrying capacity of the lagoon for pearl oyster farming implies determining the food resource available to the oysters. It is generally assumed that filter-feeding species rely on phytoplankton as their main source of energy, but only a few studies have been concerned specifically with the feeding behaviour of the pearl oyster (Chellam 1983, Nasr 1984, Hawkins et al. 1998, Yukihira et al. 1998a,b, 1999, Pouvreau et al. 1999, 2000a). Because these benthic bivalves are reared in a suspended position they interact with the planktonic food web. In the oligotrophic environment of the atoll lagoons, the structure of the planktonic food web is characterized by a predominance of pico- and nanophytoplankton (Charpy 1996, Niquil et al. 1998); the former being weakly retained by the pearl oyster (Pouvreau et al. 1999, Yukihira et al. 1999). This apparently unfavourable trophic environment currently supports high densities of vigorously growing farm-reared oysters (Pouvreau et al. 2000b). Several mechanisms may explain this paradox, e.g. a high clearance rate. However, it implies an efficient exploitation of the trophic resource.

The objectives of the present study were: (1) to qualitatively and quantitatively characterize the planktonic community in the water column, and (2) to determine the in situ feeding behaviour of Pinctada margaritifera by comparing the composition of suspended particles in the lagoonal water and that of the gut contents of reared animals. Two different methods were used; optical microscopy and HPLC pigment analysis.

\section{MATERIAL AND METHODS}

Study sites. Takapoto Atoll $\left(14^{\circ} 30^{\prime} \mathrm{S}, 145^{\circ} 20^{\prime} \mathrm{W}\right)$ is located in the Tuamotu Archipelago, in the north of French Polynesia (Fig. 1). Since 1977, this lagoon has been the most frequently used site for studies concerning the pearl oyster, firstly during the UNESCO Man And Biosphere program (Salvat 1976) and later as a part of PGRN. The lagoon has a surface area of $81 \mathrm{~km}^{2}$ and an average depth of $25 \mathrm{~m}$ (Zanini 1997). The main feature of this atoll is the absence of a pass, which restricts water flow between the lagoon and the ocean. During high swells and/or strong winds, oceanic waters can enter the lagoon through reef-flat spillways which are mostly situated on the eastern part of the atoll. The residence time of water in the lagoon was estimated to be 4.2 yr (Sournia $\&$ Ricard 1976). Prevailing winds come from the east and are considered to be the main forcing factor within the lagoon since tides are negligible (Rougerie 1979).
Three sampling sites representing different environmental conditions were chosen (Fig. 1). The location of the sites depended on logistic constraints (e.g. sampling at nighttime a short distance from the laboratory). Stn 1 was located in the south part of the lagoon. It was investigated during the first phase of PGRN (Charpy et al. 1992) and was the reference site for the experiments on the ecophysiology of the pearl oyster (Pouvreau et al. 2000a). Because Stn 1 was located in a somewhat confined part of the lagoon-due to the existence of an east-to-west submerged coral structure-Stn 2 was located further north, in the eastern part of the lagoon. Stn 2 had also been sampled during the first part of PGRN (Charpy 1996) and was simultaneously sampled in a companion study on the planktonic food-web (Sakka et al. 1999). Stn 3 was situated approximately on the central axis of the lagoon, near pearl oysters rearings.

Sampling procedure. Sampling was performed from 17 to 24 April 1997. Water was sampled every $3 \mathrm{~h}$ during $24 \mathrm{~h}$ from 06:00 $\mathrm{h}$. The gut contents were collected every $6 \mathrm{~h}$. Water samples were collected at $7 \mathrm{~m}$ depth (i.e. same depth as oysters in our experiment) using an electric pump. For HPLC analysis, triplicates of 21 water samples were filtered firstly on a $200 \mu \mathrm{m}$ nylon net to discard large zooplankton, then through glassfibre filters Whatman GF/F (nominal porosity $0.7 \mu \mathrm{m}$, $25 \mathrm{~mm} \varnothing$ ). The filters were kept frozen in liquid nitrogen pending HPLC analysis. For microscopic analysis, triplicates of $250 \mathrm{ml}$ water samples were preserved by

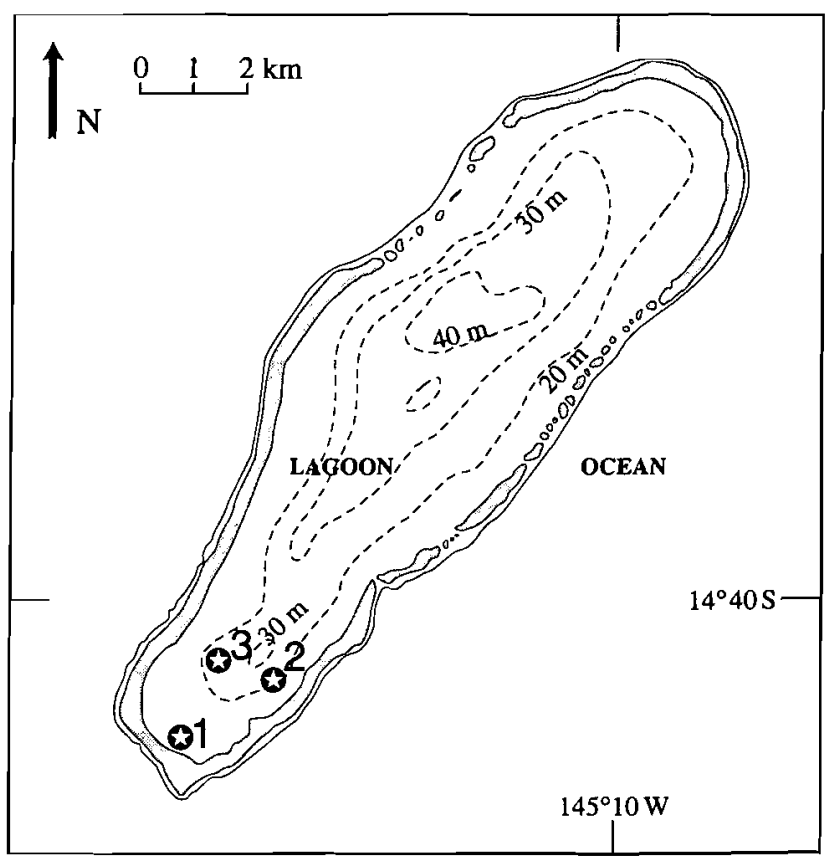

Fig. 1. Map of the Takapoto Atoll with the 3 sampling sites (Stns 1, 2,3) 
the addition of formaldehyde (final concentration $3.7 \%$ ) and kept in the dark pending enumeration under the optical microscope.

Pearl oysters originated from rearings of the Service des Ressources Marines (SRM). They were suspended on ropes at $7 \mathrm{~m}$ depth (i.e. the usual depth for reared pearl oysters) and thus kept in their natural water environment. In order to analyse digested food separately from recently ingested food, the digestive tracts of the bivalve were dissected into 2 parts. The proximal part of the gut was considered as the portion of the digestive tract between oesophagus and stomach, whereas the distal part corresponded to the intestine between the digestive gland and the anus. The material collected in 1 gut of bivalve did not contain enough pigment material to be detected and analysed with the HPLC technique. Consequently, the distal and proximal parts of the gut contents of 4 oysters were pooled by suspension in known volumes of GF/F filtered seawater and kept frozen in liquid nitrogen.

Microscope analysis. Water and gut samples were left to settle for $24 \mathrm{~h}$ in a $100 \mathrm{ml}$ and a $5 \mathrm{ml}$ sedimentation chamber (Hydro-Bios combined plate chambers), respectively. Enumeration was achieved according to Utermöhl (1958), using an inverted microscope Olympus IMT at magnifications of $100 \times$ and $400 \times$. As epifluorescence was not available, picoplankton were not enumerated. The phytoplankton cells numbers were determined for the major taxonomic groups. Additionally, the cell size $(\mu \mathrm{m})$ was determined on 100 randomly selected cells in both water and gut content samples. For each taxonomic group, cell counts were expressed as percent of total enumerated cells.

Pigment analysis by HPLC. The pigments were extracted in $100 \%$ methanol for $1 \mathrm{~h}$ at $4^{\circ} \mathrm{C}$ in the dark, sonicated for $30 \mathrm{~s}$ (Wright et al. 1991), then centrifugated at $1000 \times g$ for $10 \mathrm{~min}$. The marker pigments of phytoplankton for the different algal groups were analysed by HPLC using a method described by Kraay et al. (1992) which allows effective separation of lutein and zeaxanthin. The system consisted of 3 Kontron HPLC Pumps (series 400) monitored by a Kontron computer and 2 detectors in series. Absorption measurements were performed using a photodiode array detector (Kontron, model 440) at $440 \mathrm{~nm}$. The fluorescence of chlorophylls and phaeopigments were measured using a spectrofluorimetric detector (Kontron Analytical SFM 25) with an excitation wavelength of $430 \mathrm{~nm}$ and a $663 \mathrm{~nm}$ cutoff secondary filter for emission. The pigments were analysed by reverse-phase HPLC using a BIO-RAD Bio-Sil C18 HL 90-5 S (150 mm long, $4.6 \mathrm{~mm} \varnothing$ and $5 \mu \mathrm{m}$ particle size) column and HPLC-grade solvents.

Some standards were obtained commercially: chlorophylls (chl) $a$ and $b, \beta, \beta$-carotene (Sigma Chemical Company) and 19'-hexanoyloxyfucoxanthin from VKI (Water
Quality Institute, Denmark). Lutein and zeaxanthin were kindly provided by Hoffman LaRoche Co. (Basel, Switzerland). Other pigments were obtained from monospecific algal cultures and then purified according to Pastoureaud et al. (1996). These standards were transferred to the adequate solvent and measured on a Shimadzu UV-160 spectrophotometer, using specific absorption coefficients as indicated by Bidigare (1991).

HPLC data analysis. Water column: There is already abundant literature about the contributions of the major phytoplanktonic groups in terms of chl a determined using the marker concentrations. Our study aimed to accurately determine the value of the pigment ratio in order to link the concentration of 1 pigment to the corresponding chl a concentration. An earlier method by Gieskes et al. (1988) used a multiple regression analysis to infer the values of the pigment ratios from the measured dataset. A new program for estimating class abundances from chemical markers, so-called CHEMTAX, was developed by Mackey et al. (1996) and applied by Wright et al. (1996) and Meyer-Harms et al. (1999). But this method was not applicable to our dataset because it requires a previous knowledge of the pigment ratios of the local populations. In contrast, the technique proposed by Goericke \& Montoya (1998) was based on the use of ratios derived from the literature. However, this approach lacked an objective statistical analysis. Letelier et al. (1993) considered that not all species had a unique specific marker pigment, but these authors insufficently explicited their use of the inverse method to solve this problem. Using the Letelier et al. (1993) statements, we developed a new method to determine the pigment ratios.

If a given marker pigment Mi could be assigned to a specific algal group (Table 1), the relationship between chl $a$ and the $n$ concentrations of the detected marker pigments $\mathrm{Mi}$ would be written as follows:

$$
\operatorname{chl} a=x_{1}[\mathrm{M} 1]+x_{2}[\mathrm{M} 2]+x_{3}[\mathrm{M} 3]+\ldots x_{n}[\mathrm{Mn}]
$$

where $x_{i}$ represent the chl a:Mi ratio for a given algal group $i$.

Table 1. Main pigments, used as taxonomic markers, and size of the corresponding algal groups. Zeaxanthin (zea), Fucoxanthin (fuco), chlorophyll $b$ (chl b), Peridinin (per), Alloxanthin (allo), 19'-hexanoyloxyfucoxanthin (19'hf)

\begin{tabular}{|lcc|}
\hline Phytoplankton group & Marker pigment & Size $(\mu \mathrm{m})$ \\
\hline Cyanophytes & Zea & $<1$ \\
Diatoms & Fuco & $>20$ \\
Chlorophytes & Chl $b$ & $1-40$ \\
Dinoflagellates & Per & $>10$ \\
Cryptophytes & Allo & $5-10$ \\
Prymnesiophytes & $19^{\prime} \mathrm{hf}$ & $5-20$ \\
\hline
\end{tabular}


This equation did not take into account the fact that 2 markers are each contained in 2 different groups of algae. Diatoms and prymnesiophytes contain fucoxanthin and cyanobacteria and chlorophytes contain zeaxanthin. Thus, for the 6 marker pigments detected in Takapoto lagoon, Eq. (1) became

$$
\begin{aligned}
\text { chl } a= & x_{1}[\text { allo }]+x_{2}[\text { perid }]+x_{3}\left[19^{\prime} \text { hf }\right] \\
& +x_{4}\left([\text { zea }]-x_{5}[\text { chl } b]\right)+x_{6}[\text { chl } b] \\
& +x_{7}\left([\text { fuco }]-x_{8}\left[19^{\prime} \text { hf }\right]\right)
\end{aligned}
$$

where the contribution of chlorophytes to the zeaxanthin concentration $\left(x_{5}=\mathrm{zea} / \mathrm{chl} b\right)$ are subtracted, as well as the contribution of prymnesiophytes to the fucoxanthin concentration $\left(x_{8}=\right.$ fuco/19'hf).

The model described by Eq. (2) is non-linear and consequently it was impossible to find a solution using a multiple-linear regression. Besides, as some explanatory variables are repeated with different parameters, (e.g. [chl b] and [19'hf]), Eq. (2) provided an infinity of solutions. Additional criteria allowed the interval of acceptable solutions to be restrained. Firstly, all the contributions, including the terms [zea] $-x_{5}[\mathrm{chl} b]$ and [fuco] $-x_{8}\left[19^{\prime} h f\right]$, should be positive. Secondly, the previous knowledge on the range of pigment ratios (Table 2) was used as inequality constraints. We explored the space of the solutions through a simple, empirical and iterative computation. Considering that $x_{8}$ is accurately known due to the narrow range reported in the literature $(0.03$ to 0.05 . Table 2$)$, the redundancy of the parameters could be overcome by considering a priori values of $x_{5}$. Since the only information on $x_{5}$ came from the known range of values (Table 2), we drew 100 values of $x_{5}$ at random. For each value of $x_{5}$, Eq. (2) became linear and could be

Table 2. Literature ranges of chl a to marker pigment ratios used to determine the different amounts of the algal classes

\begin{tabular}{|c|c|c|c|}
\hline $\begin{array}{l}\text { Equation } \\
\text { parameter }\end{array}$ & Pigment ratio & Literature range & Source \\
\hline$x_{1}$ & Chl a/allo & $1.8-4.2$ & $a, b, c$ \\
\hline$x_{2}$ & Chl a/per & $1.4-2.8$ & $b, d, e, f$ \\
\hline$x_{3}$ & Chl $a / 19^{\prime} h f$ & $0.7-3.2$ & $\mathbf{g}, \mathbf{h}, \mathbf{i}, \mathbf{j}$ \\
\hline$x_{4}$ & Chl a/zea & $0.5-2.1$ & $a, k, l$ \\
\hline$x_{6}$ & Chl $a / \operatorname{chl} b$ & $1.5-2.7$ & $\mathbf{m}, \mathbf{n}$ \\
\hline$x_{7}$ & Chl a/fuco & $1.3-2.3$ & $h, o, p$ \\
\hline$x_{8}$ & Fuco/19'hf & $0.03-0.05$ & $\mathrm{i}, \mathrm{j}, \mathrm{l}$ \\
\hline \multicolumn{4}{|c|}{$\begin{array}{l}\text { (a) Hager \& Stransky (1970), (b) Burkill et al. (1987), (c) Claus- } \\
\text { tre et al. (1994), (d) Vesk \& Jeffrey (1977), (e) Bjornland \& } \\
\text { Tangen (1979), (f) Jeffrey et al. (1975), (g) Wright \& Jeffrey } \\
\text { (1987), (h) Bidigare (1989), (i) Buma et al. (1991), (j) Vaulot } \\
\text { et al. (1994), (k) Kana et al. (1988), (l) Letelier et al. (1993), } \\
\text { (m) Hooks et al. (1988), (n) Simon et al. (1994), (o) Bustillos- } \\
\text { Guzmàn et al. (1995) and (p) Tester et al. (1995) }\end{array}$} \\
\hline
\end{tabular}
contributing to total chl a. See Table 1 legend for marker pigment abbreviations solved with the use of a least-square algorithm in order to minimise differences between chl a values observed and calculated (linear regression with constraints). This method was applied to the 72 data of $\mathrm{chl}$ a obtained at the 3 sampling sites. It therefore provided 100 sets of parameters $x_{i}$, which were acceptable solutions to Eq. (2) from which we computed the mean and standard deviations of each pigment ratio. The pigment ratios were used to calculate the contributions of algal groups in terms of chl $a$ in the water column.

Gut contents: At the 3 sites, the proportions of each algal group in the water and the gut contents were determined every $6 \mathrm{~h}$ throughout the $24 \mathrm{~h}$ survey. During each sampling, we compared the proportions in the water and in the gut contents (chi-square test); assuming that each marker pigment was specific to 1 algal group (Table 1). Because chl $b$ co-eluted with a chl $c$-like, the lutein was used instead of chl $b$ to evaluate the contribution of chlorophytes. The method based on the chl a pigment ratios developed for the water column could not be applied to the gut contents because of the scarcity of informations on the chl $a$ : lutein ratio. Consequently, the proportions of the main phytoplanktonic groups were calculated as percentages of the total marker carotenoids. The same calculation was applied to water samples for comparison with the gut contents.

\section{RESULTS}

\section{Lagoonal water composition}

The HPLC analysis provided the elution pattern of chlorophylls and carotenoid pigments as illustrated by the absorbance chromatogram presented in Fig. 2. The major pigments were chls $a$ and $b$, chl $c_{1+2}, 19^{\prime}$-hexanoyloxyfucoxanthin $\left(19^{\prime} \mathrm{hf}\right)$, zeaxanthin and $\beta, \beta$-carotene. In contrast, peridinin, alloxanthin and fucoxanthin showed minor peaks. It is important to emphasise that we considered that the 19 'hf was the exclusive marker of the prymnesiophytes in the Takapoto lagoon. In fact, several types of pigment composition were identified in prymnesiophytes (Jeffrey \& Wright 1994). In our samples, the presence of 19 'hf and chl $c_{3}$, the absence of $19^{\prime}$ bf and the low amount of fucoxanthin clearly indicated that the prymnesiophytes of Takapoto lagoon belonged mainly to the $19^{\prime} \mathrm{hf}-\mathrm{chl} c_{3}$ group.

The contributions of the main phytoplanktonic groups (Fig. 3) were calculated from the estimations of pigment ratios evaluated by the data analysis method (Table 3). Stn 1 was dominated by cyanobacteria, which represented more than $55 \%$ of total chl a. At this station, the second major phytoplanktonic class was chlorophytes which contributed $15 \%$ of the total chl $a$. 
Table 3. Mean and standard deviation (SD) of the piginent ratio values estimated by our model and used to determine the contributions of the main phytoplanktonic groups in the water column. See Table 1 legend for marker pigment abbreviations

\begin{tabular}{|lccc|}
\hline $\begin{array}{l}\text { Equation } \\
\text { parameter }\end{array}$ & Pigment ratio & Mean & SD \\
\hline $\boldsymbol{x}_{1}$ & Chl a/allo & 4.20 & 0.15 \\
$\boldsymbol{x}_{2}$ & Chl a/per & 1.40 & 0.09 \\
$\boldsymbol{x}_{3}$ & Chl $a / 19$ 'hf & 1.28 & 0.05 \\
$\boldsymbol{x}_{4}$ & Chl $a /$ zea & 1.38 & 0.03 \\
$\boldsymbol{x}_{5}$ & Zea/chl $b$ & 0.20 & 0.09 \\
$\boldsymbol{x}_{6}$ & Chl $a /$ chl $b$ & 1.53 & 0.06 \\
$\boldsymbol{x}_{7}$ & Chl $a /$ fuco & 1.30 & 0.12 \\
$\boldsymbol{x}_{8}$ & Fuco/19'hf & 0.03 & 0.001 \\
\hline
\end{tabular}

However, Stns 2 and 3 were characterized by 3 main algal classes (prymnesiophytes, cyanobacteria and chlorophytes), whose contributions were respectively estimated to 40,25 and $20 \%$ of total chl a.

Microscopic analyses (Fig. 4) showed that chlorophytes and dinoflagellates were predominant in lagoon water. Among chlorophytes, Chlamydomonas sp., ca 10 to $12 \mu \mathrm{m} \varnothing$, was the most frequently identified genus-whereas dinoflagellates were represented by Gymnodinium sp. and Prorocentrum sp., whose size equalled 18 and $25 \mu \mathrm{m}$, respectively. Small pennate diatoms and coccolithophorids were less frequently observed. Chlorophytes made the bulk of nanophytoplankton at Stn 1, whereas dinoflagellates were predominant at Stns 2 and 3. No nycthemeral variation could be outlined using either microscopy or HPLC methods.

\section{Composition of the gut contents}

The absorbance chromatogram (Fig. 2) showed the diversity of pigments detected using HPLC. All the marker pigments of the algal groups encountered in the water were present in the guts. In addition, 2 pigments which were absent in the water column were detected: the diatoxanthin, a carotenoid involved with diadinoxanthin in photoprotection processes, and a pigment, identified as a chl $c$-like, which coeluted with chl $b$. Its absorption spectrum (444-582-630.5) showed maxima very near from those of $\mathrm{chl} \mathrm{c}_{2}$. This pigment was present mainly in the distal part of the gut where its concentration, calculated using the chl $c_{2}$ coefficient, corresponded to $1-5 \%$ of the total pigments. The degradation forms of either chlorophylls (both phaeophorbides and phaeophytins) or carotenoids represented a very small part of the detected pigments. This was also true in the distal part of the guts where significant amounts of native chl a were encountered.
The proximal part of the guts was characterized by high amounts of alloxanthin, 19'hf and chls $a$ and $b$. Three major pigments - 19 'hf, alloxanthin and chl $b$ were detected in the proximal part of the gut at Stns 2 and 3 (Fig. 5), whereas the alloxanthin was the major carotenoid detected at Stn 1 (20 to $90 \%$ of the total biomarkers). The number of marker pigments detected in the distal part of the guts was higher than in the proximal one (Fig. 5), although the food had already been subjected to the digestive processes.
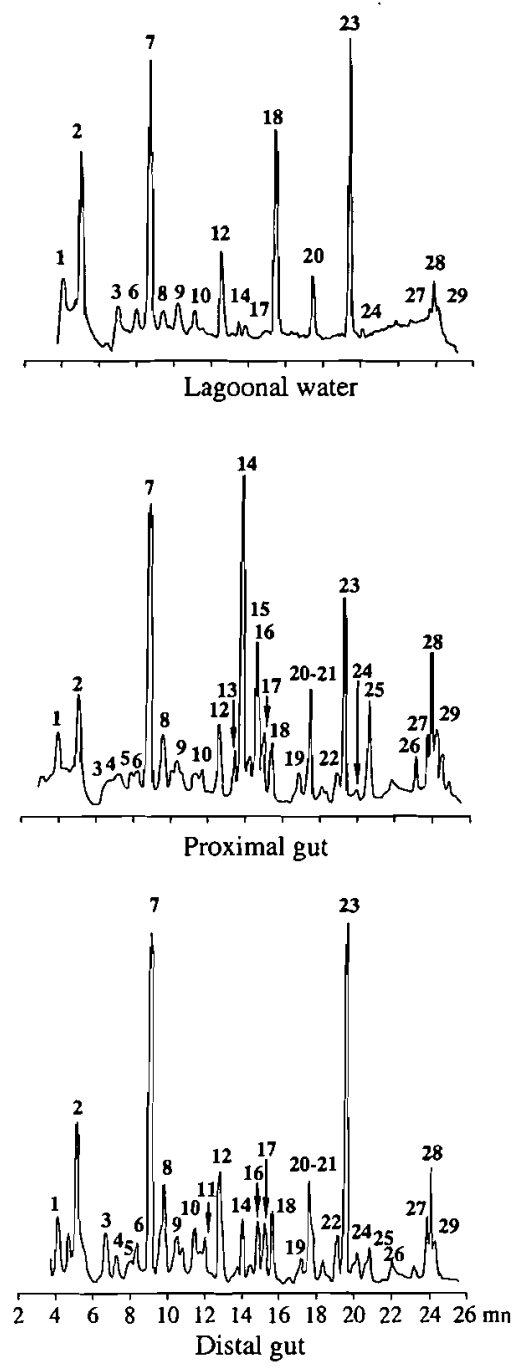

Fig. 2. Absorbance chromatograms of phytoplankton pigments at Stn 3 in (a) water, (b) in the proximal and (c) distal parts of the gut of Pinctada margaritifera. Pigment identifications: (1) chl $c_{3} ;$ (2) chl $c_{2 i}$ (3) peridinin; (4) siphonaxanthin; (5) chl $c_{i}$ (6) fucoxanthin; (7) 19'hexanoyloxyfucoxanthin; (8) 9'-cisneoxanthin; (9) prasinoxanthin ${ }_{i}(10)$ violaxanthin ${ }_{i}(11)$ phaeophorbid a-like; (12) diadinoxanthin; (13) antheraxanthin; (14) alloxanthin; (15) monadoxanthin; (16) diatoxanthin; (17) lutein; (18) zeaxanthin; (19) chl b-like; (20) chl $b_{i}(21) \mathrm{chl} c$ like; (22) chl a allomer; (23) chl $a$; (24) and (25) chl a epimers; (26) phaeophytin $a_{;}$(27) $\beta, \alpha$-carotene; (28) $\beta, \beta$-carotene; (29) $\beta, \psi$-carotene 
The predominant food items identified during microscopic examination of the gut contents are summarized in Table 4. Six algal groups ranging in size from 6 to $50 \mu \mathrm{m}$ were encountered in the gut of oysters; consisting mainly of chlorophytes at Stn 1 and dinoflagellates
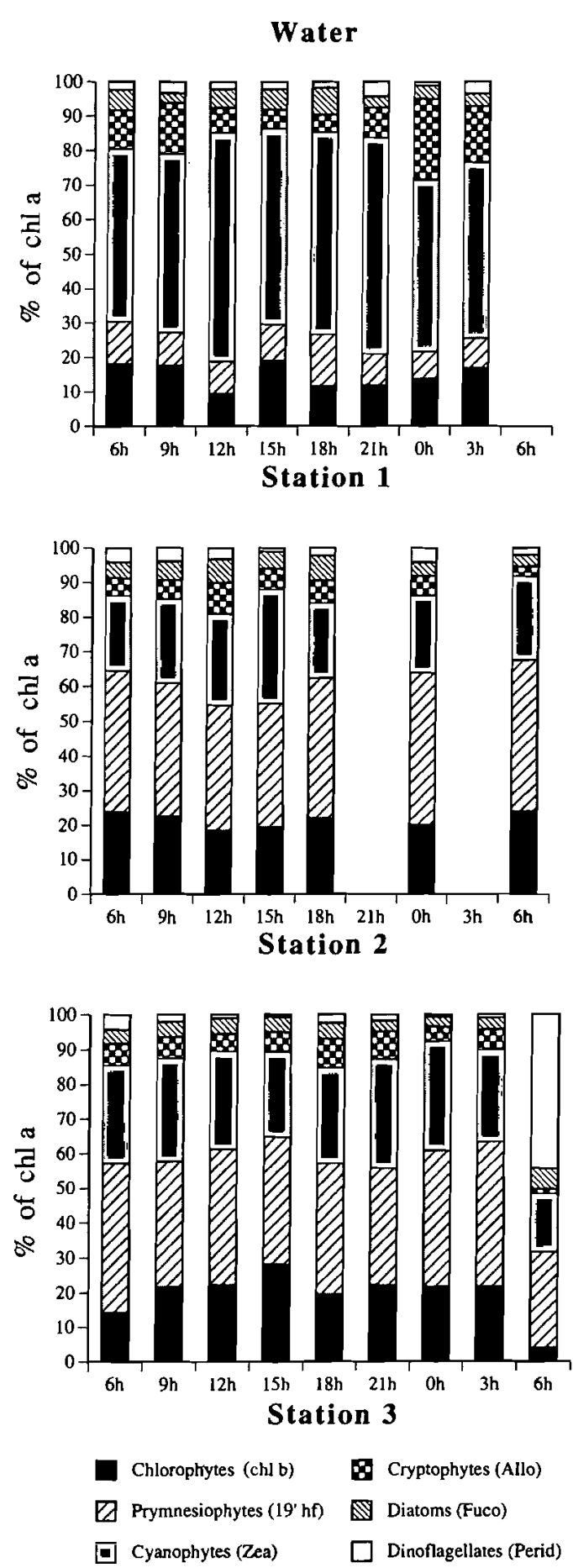

Fig. 3. Contribution of the main phytoplanktonic groups in the lagoonal water at each sampling station estimated by HPLC pigment analysis and expressed in percent of total $\mathrm{chl} \mathrm{a}$

at Stns 2 and 3 (Fig. 4). Pinctada margaritifera also ingested zooplankton, e.g. bivalve larvae, invertebrate eggs, small copepods and protozoans.

Water

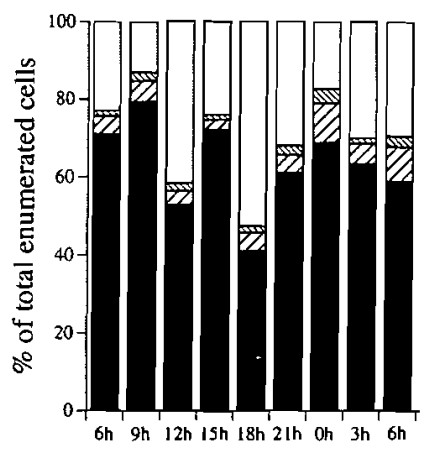

Gut
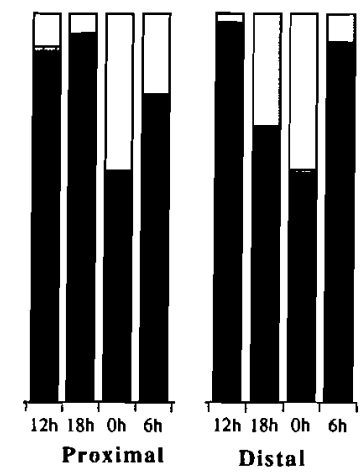

Station 1
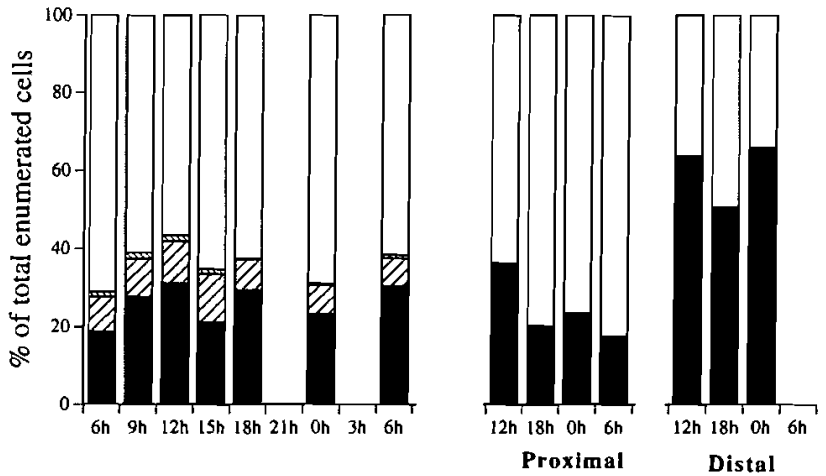

Station 2
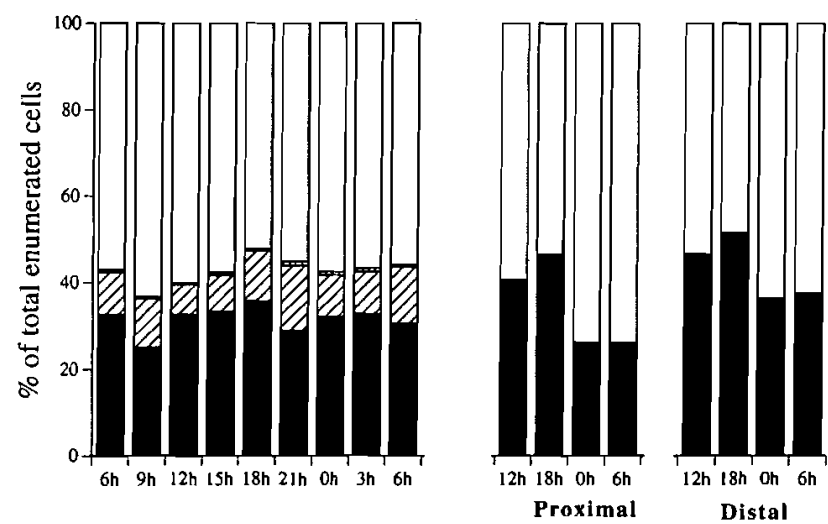

Station 3

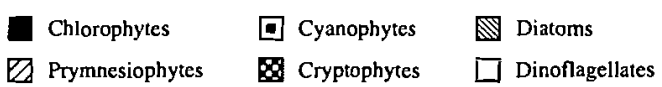

Fig. 4. Contribution of the main phytoplanktonic groups in the lagoonal water and in the proximal and distal parts of the gut at each sampling station using optical microscope and expressed in percent of the total enumerated cells. Picoplankton and small nanoflagellates were not taken into account 
Table 4. Main phytoplanktonic species (with their size) identified in the gut contents of the pearl oysters Pinctada margaritifera in the Takapoto lagoon

\begin{tabular}{|llc|}
\hline Algal group & $\begin{array}{l}\text { Dominant phytoplankton } \\
\text { species }\end{array}$ & $\begin{array}{c}\text { Cell dia- } \\
\text { meter }(\mu \mathrm{m})\end{array}$ \\
\hline Chlorophytes & Chlamydomonas sp. & $10-12$ \\
Prasinophytes & Nephroselmis sp. & $6-8$ \\
Prymnesiophytes & Cricosphaera sp. & 18 \\
Cryptophytes & Leucocryptos sp. & 10 \\
Diatoms & Navicula sp. & 30 \\
& Nitzschia sp. & 25 \\
Dinoflagellates & Gymnodinium sp. & 18 \\
& Oxytoxum sp. & 14 \\
& Prorocentrum scalpellum & $45-50$ \\
& Prorocentrum sp. & 35 \\
\hline
\end{tabular}

\section{Comparisons between the gut contents and the water}

The comparison of the proportions of the marker pigments between the water and the proximal part of the gut contents (Fig. 5) showed significant differences $(p<0.05)$. For each marker pigment, the ratio between the proportions estimated in the water and in the guts was calculated (Table 5). The values of the ratio ranged from 0 to 79.7. The highest value was obtained for alloxanthin. It showed evidence of a high cryptophyte accumulation in the proximal part of the gut contents, regardless which station and which sampling hour was considered. On the contrary, the ratios of the other marker pigments were low, except for peridinin at Stn 3.

The comparison between the proportions of the algal groups determined by the microscope did not show significant differences between water and gut contents. The composition of the gut contents appeared quite similar to that of the water column (i.e. dominance of chlorophytes or dinoflagellates). Diatoms and prymnesiophytes which were observed as minor groups in the water were not identified in the gut contents.

\section{DISCUSSION}

Two methodological approaches were used to assess the phytoplankton composition and abundance in the water and in the gut contents of the pearl oyster. Although the advantages and limits of microscope and HPLC methods have already been widely discussed (e.g. Wilhelm et al. 1991, Schlüter \& Havskum 1997), these methods were sucessfully used to investigate the ingestion rate of the copepod Acartia bifilosa (MeyerHarms \& von Bodungen 1997). The present study reports the first in situ study on the qualitative composition of the diet of a filter-feeding bivalve using the combined approach of HPLC pigment analysis and microscopy. As expected, microscopic examination and HPLC analysis did not provide identical results.

The HPLC method identified and quantified the nano- and picophytoplanktonic organisms which dominated the autotrophic community in the Takapoto lagoon. As most of the cyanobacteria were ca $1 \mu \mathrm{m} \varnothing$ (Charpy \& Blanchot 1998), they were not detected under the optical microscope without fluorescence.
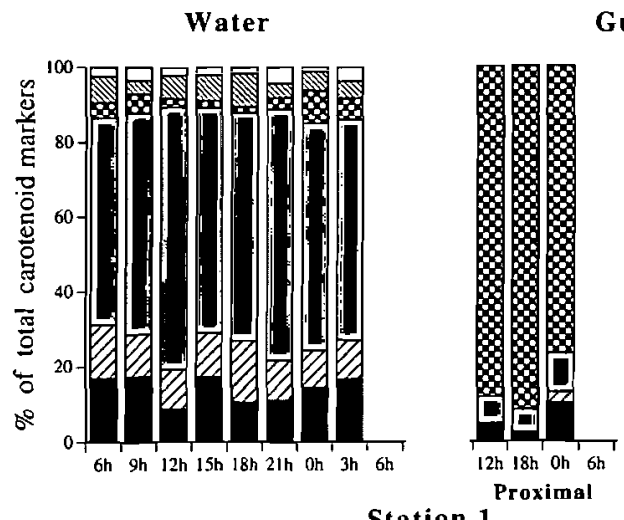

Gut

Station 1
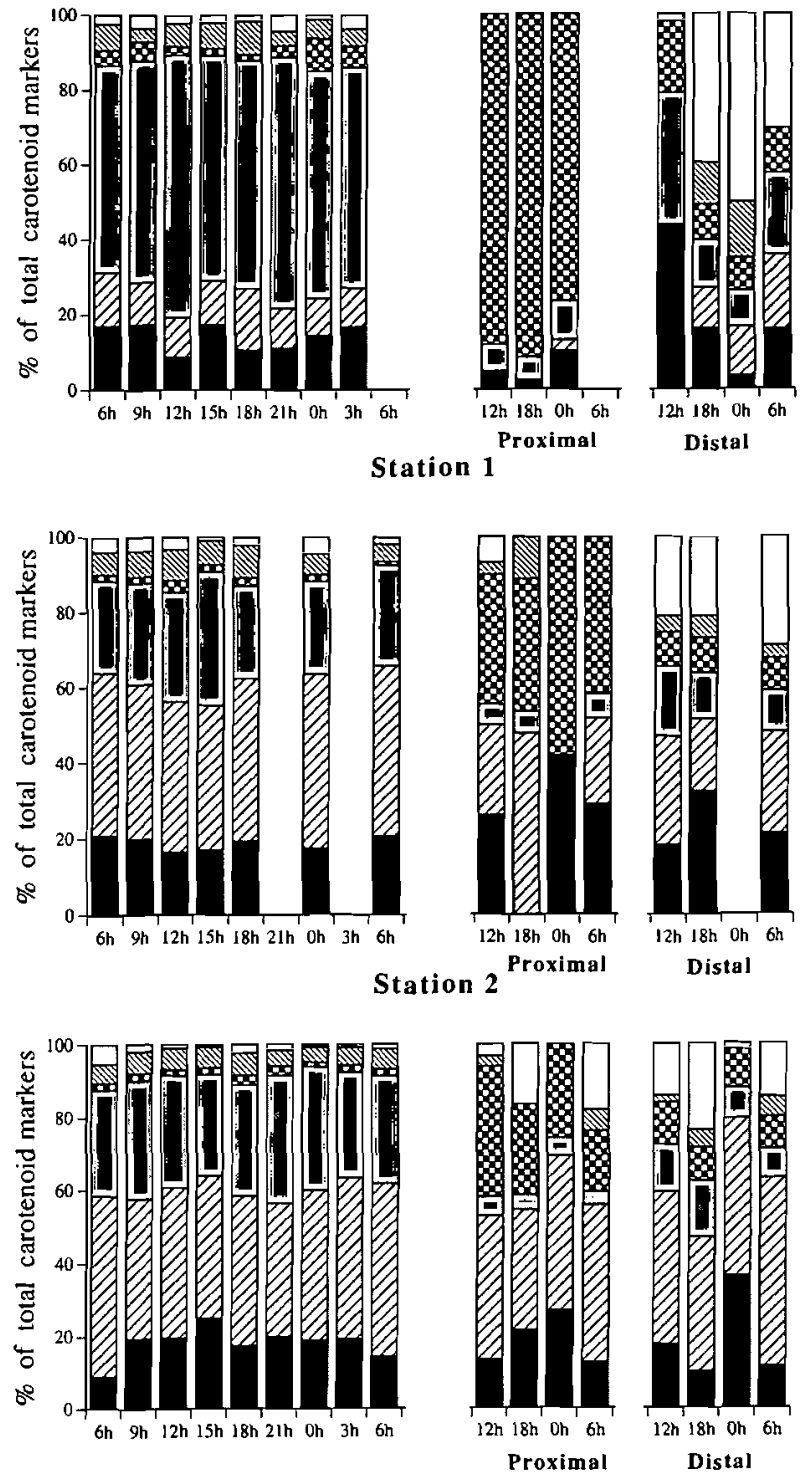

Station 3

Distal

Chlorophytes (Lut) 回 Cyanophytes (Zea) Diatoms (Fuco)

Prymnesiophytes (19' hf) Cryplophytes (Allo) $\square$ Dinoflagellates (Perid)

Fig. 5. Contribution of the main phytoplanktonic groups in the lagoonal water and in the proximal and distal parts of the gut at each sampling station estimated by HPLC pigment analysis and expressed in percent of total carotenoid markers 
Table 5. Ratios between the proximal part of the gut and the water column for the main marker pigments at the 3 sampled stations at different sampling times. Lutein (lut), see Table 1 for other marker pigment abbreviations

\begin{tabular}{|lrrrrrrrrrrrrrr|}
\hline & \multicolumn{4}{c}{ Stn 1 } & \multicolumn{4}{c}{ Stn 2} & \multicolumn{4}{c|}{ Stn 3} \\
& $12 \mathrm{~h}$ & $18 \mathrm{~h}$ & $0 \mathrm{~h}$ & $6 \mathrm{~h}$ & $12 \mathrm{~h}$ & $18 \mathrm{~h}$ & $0 \mathrm{~h}$ & $6 \mathrm{~h}$ & $12 \mathrm{~h}$ & $18 \mathrm{~h}$ & $0 \mathrm{~h}$ & $6 \mathrm{~h}$ \\
\hline Per & 0.0 & 0.0 & 4.6 & - & 1.8 & 0.0 & - & 0.0 & 1.6 & 21.5 & 0.0 & 22.0 \\
Fuco & 0.0 & 0.0 & 0.0 & - & 0.5 & 1.7 & - & 0.0 & 0.4 & 0.0 & 0.0 & 1.1 \\
19 'hf & 0.0 & 0.0 & 13.8 & - & 0.6 & 1.2 & - & 0.5 & 1.0 & 0.7 & 1.1 & 1.0 \\
Allo & 16.2 & 45.6 & 79.7 & - & 19.8 & 17.2 & - & 40.7 & 17.9 & 11.6 & 9.0 & 8.6 \\
Lut & 0.3 & 0.1 & 2.6 & - & 1.3 & 0.0 & - & 1.3 & 0.7 & 0.7 & 1.2 & 0.7 \\
Zea & 0.1 & 0.1 & 0.8 & - & 0.2 & 0.2 & - & 0.2 & 0.2 & 0.1 & 0.1 & 0.1 \\
\hline
\end{tabular}

most of the dinoflagellates were heterotrophic. This observation was confirmed by Sakka et al. (1999) in a companion study. The absence of pigmentation and the lack of peridinin are known to characterize a great number of dinoflagellate species (Hallegraeff \& Jeffrey 1984), and this heterotrophy has been underlined in reef environments (Sournia \& Ricard 1976). Abundant literature is available on the trophic status of the dinoflagellates (Gaines \& Taylor 1984, Lessard \& Swift

Similarly, the nanoflagellates, which constituted a major phytoplanktonic community in the pearl oysters diet, were mostly detected by the pigment analysis. Formaldehyde preservation often damages these small and fragile algae (Gieskes \& Kraay 1983). In particular, the algae lacking a theca, or a thick cell wall (e.g. cryptophytes or chromulins) can be deformed and thus escape microscopic enumeration. The microscope detection and identification of ingested algae are hindered in the gut of the oysters as they are mixed with detritus, and, are partly degraded. Considering the digestive process, even if the ingested material is partially digested, we assume that the pigment degradation is minimal in the proximal part of the guts.

The HPLC-pigment analysis seems to be a suitable method to obtain a realistic quantitative composition of either lagoonal phytoplankton or gut contents. However, it implies that the amount of a detected pigment precisely reflects the contribution of the corresponding algal class to the total biomass. As already mentioned ('Material and methods'), various techniques have been developed in order to link pigments concentrations to the relative abundance of an algal class. However, none of them have proved to be completely satisfactory. We do not claim that the model that we developed for the water samples is superior to previously formulated models, especially because our model likewise assumed that the pigment ratios were little varying at all the sampling sites during the nycthemeral cycle. A confirmation of this assumption would require further studies involving cultures of algal strains isolated from different places in the lagoon. Our model, however, differed in the way that the estimated pigment ratios were based on a statistical analysis of the pigment dataset.

As mentioned, the HPLC method presents several advantages. Nevertheless, the present study demonstrated the interest of the microscopic method in such a lagoonal environment. For example, in water samples, the dinoflagellates were only detected using a microscope - whereas their specific marker, the peridinin is one of the minor peaks on the HPLC chromatograms. This discrepancy indicates that, in the Takapoto lagoon,
1985, Gaines \& Elbrächter 1987, Stoecker et al. 1997). They are particularly concerned with the dinoflagellates Gymnodinium and Prorocentrum, which were the predominant genus identified in the water column and are known to contain auto-, mixo- and heterotrophic species. From the above observations, it can be concluded that both methods are necessary in order to completely describe the planktonic community in the Takapoto lagoon: The HPLC method showed the predominance of small forms (picocyanobacteria and nanophytoflagellates) among the autotrophic communities and the microscopy confirmed the importance of heterotrophic dinoflagellates presence.

Analysis of the water samples indicated that the mother-of-pearls Pinctada margaritifera were open to a choice in different food items, according to their location in the lagoon. The picocyanobacteria predominated at Stn 1 . Those algae $<1 \mu \mathrm{m}$ were still present (ca 20\%) but a complex of nanoflagellates (chlorophytes and prymnesiophytes) and microplankton (dinoflagellates) were predominant at Stns 2 and 3. The quantitative importance of picocyanobacteria in Takapoto lagoon (and particularly Synechococcus sp.) has been evidenced from fractionated carbon, chlorophyll and primary production measurements (Charpy et al. 1992, Charpy \& Blanchot 1996, 1998). At the time of our study, this dominance applied only in the south part of the lagoon. A small chlorophyte Chlamydomonas sp. predominated in the $>3 \mu \mathrm{m}$ fraction at Stn 1 and was also reported from the Takapoto lagoon in a companion study (Sakka et al. 1999). However, chlorophytes were still present at Stns 2 and 3 but in lower proportions compared with prymnesiophytes. Small phytoflagellates had not been recorded in the waters of the Takapoto lagoon since Sournia \& Ricard's (1976) pioneer studies, which mainly focused on diatoms and dinoflagellates. Due to the limited examination of phytoplankton during more than $20 \mathrm{yr}$, it cannot be stated if those drastic changes in the phytoplankton composition reflect a temporal evolution, or if they could be attributed to more sophisticated investigation methods. The high abundance of prymnesiophytes has not been pre- 
viously reported. Toxic species of this class with a similar pigment signature are frequently involved in algal blooms (Jeffrey \& Wright 1994).

A spatial homogeneity in the composition of the phytoplanktonic communities was observed at Stns 2 and 3 (Fig. 3) and is in agreement with the lack of spatial variability mentioned by Buestel \& Pouvreau (2000) at the lagoon scale. The differences observed in the composition of these communities at Stn 1 could be explained by the influence of anthropic outputs from the village, located in the south part of the atoll (Charpy et al. 1997). No significant differences (ANOVA, $\alpha=5 \%$ ) in the phytoplanktonic composition of the water column and of the gut contents were observed during the nycthemeral cycles. As a consequence, the temporal variability of the phytoplankton composition in the lagoon was low. It does not corroborate to the observations carried out in the lagoon of atolls which showed an increase in the autotrophic biomass and production at the end of the day (Charpy 1996, Buestel \& Pouvreau 2000).

Pearl oysters poorly ingest picocyanobacteria as the content of zeaxanthin in the proximal part of the gut (Fig. 5) is low and may, partly, be attributed to chlorophytes. The low abundance of cyanobacteria in the gut of the bivalve could be related to the low retention of particles $<2 \mu \mathrm{m}$ demonstrated by the previous studies of Pouvreau et al. (1999) and Yukihira et al. (1999). This low retention is attributed to the absence of eulatero-frontal cirri on the gill filaments. However the indirect ingestion of the picoplanktonic biomass can be mediated by heterotrophic protists which then represent a trophic link between cyanobacteria and suspension-feeders (Le Gall et al. 1997, Dupuy et al. 1999).

In the oyster gut, the HPLC analysis and the microscope examination showed that the phytoplankton $>3 \mu \mathrm{m}$ are composed mainly of 3 classes, size ranges given in Table 1; cryptophytes, chlorophytes and prymnesiophytes. The microscopic analysis evidenced a high proportion of heterotrophic dinoflagellates (not detected by the HPLC method) in the proximal part of the guts. Among the phytoplanktonic groups present in the water column, pearl oysters preferentially ingested cryptophytes (Fig. 5): alloxanthin was accumulated in the proximal part of the gut contents. These algae were poorly represented in the water samples ( $<15 \%$ of total chl a), whereas they were always found in the proximal part of the gut and even dominated at Stn 1 . The selective feeding is evidenced by highly significant differences in the alloxanthin concentration - the specific marker pigment of cryptophytes between the water column and the gut. Until now, few studies have focused on defining the available food and the feeding behaviour of the pearl oyster Pinctada margaritifera in its natural environment (Hawkins et al. 1998, Pouvreau et al. 1999, 2000a, Yukihira et al. 1999). A positive selection (i.e. preferential ingestion) of cryptophytes by any species of bivalves studied under in situ conditions has not, according to our knowledge, been mentioned before. At the time of our study, this phytoplanktonic group played a key role in the diet of Pinctada margaritifera.

The selection of cryptophytes does not seem to be based on the size of the particles. Although being of a similar size range, the prymnesiophytes and the chlorophytes, especially the $10 \mu \mathrm{m}$ Chlamydomonas sp., are not preferentially ingested because they are encountered in relatively same proportions in the water as in the gut. Two processes can be involved in the selective feeding on cryptophytes: (1) a preferential retention on the ctenidia and/or (2) a sorting on the ctenidia or labial palps (Ward et al. 1998). At present, it is impossible to evaluate the relative importance of these 2 processes. On the one hand, the preferential retention has been reported for several bivalves using flow-cytometry (Shumway et al. 1985, Newell et al. 1989, Bougrier et al. 1997). However, the mechanisms involved in this distinction have yet to be determined. On the other hand, the pre-ingestive selection of organic matter has been proved to be low for Pinctada margaritifera when compared to other bivalves (Hawkins et al. 1998, Yukihira et al. 1999, Pouvreau et al. 2000a). Although further evidence is required for making precise conclusions about the processes involved in the selection, our results demonstrate, for the first time, the capability of this bivalve to select the ingested food on a qualitative basis.

Cryptophytes are known to be high nutritive algae (Stewart \& Wetzel 1986). Yukuhira et al. (1998b) showed the importance of energy-rich and digestible particles for the energy gain of pearl oysters. Cryptophytes are considered as easily digestible organisms (Porter 1973) probably because they contain small amounts of structure material (Stewart \& Wetzel 1986). Shumway et al. (1985) and Newell et al. (1989) reported that the cryptophyte Chroomonas salina was easily digested by several bivalves.

The relative abundance in the proximal to the distal parts of the gut of the different algal classes was not identical. This was particularly characteristic in the case of peridinin, which was absent in the proximal part of the gut and abundant in the distal part. On the contrary, no significant differences could be detected for the $19^{\prime} \mathrm{hf}$. The relative abundance of a given marker pigment in the distal part of the gut must, however, be considered with great care as it results from 2 processes occurring during the transit in the gut. Firstly, the whole algae can be more or less efficiently digested by the oyster, e.g. because of its structure. Secondly, the marker pigment itself can more or less resist 
the digestive attack. Because peridinin is considered to be a fragile pigment due to its chemical structure (Repeta \& Gagosian 1987), and as dinoflagellates present a resistant cell wall, the accumulation of peridinin in the distal part of the gut indicates that the autotrophic dinoflagellates were probably not efficiently digested by the oyster. Similarly, chlorophytes are weakly digested, as attested by the presence of intact cells in the distal part of the gut, and living and motile cells in the faeces. The absence of chlorophytes digested could be related to their glycoprotein envelope (van den Hoek 1995). For chlorophytes, the 2 methods-HPLC analysis and microscope examination - collaborate to formulate evidence of their low digestibility performed by the oyster. No similar conclusion could be drawn for the other algal groups, which were only detected using HPLC analysis and whose contribution did not significantly differ between the 2 parts of the gut.

The abundance of intact dinoflagellates and chlorophytes justifies the low amount of degradation products of chlorophylls. The pigment degradation during digestive processes has been largely investigated in the grazing experiments of copepods (Kleppel \& Pieper 1984, Nelson 1989, Swalding \& Marcus 1994, BuffanDubau et al. 1996). In contrast, few data are available on the pigment destruction in the gut of bivalves (Numagushi 1985, Hawkins et al. 1986, Bayne et al. 1987, Pastoureaud et al. 1996). From our results, the digestive efficiency of the pearl oyster Pinctada margaritifera seems to be low. However, further studies are required to gain a better insight into such selective digestibility.

A chl $c$-like was identified in the gut content whereas it was undetected in the water samples. The chromatographic and absorption properties of this nonpolar chl $c$-like pigment suggest that it could derive from phytol-substituted chl cobserved in pure cultures of some prymnesiophytes (Nelson \& Wakeham 1989, Bidigare et al. 1990, Kraay et al. 1992, Zapata \& Garrido 1997, Garrido \& Zapata 1998). Kraay et al.'s (1992) analytic methods obtained the phytol-substituted chl $c$ eluting just after $\beta$-carotene. Our chl $c$-like differed from this one as it eluted earlier and with chl $b$. Thus we did not identify the same pigment as these authors, but probably rather a degraded form. This hypothesis is reinforced by the fact that this pigment was mainly detected in the distal part of the gut.

To conclude, the 2 complementary approaches used in this study aided the determination of the feeding behaviour of the pearl oyster Pinctada margaritifera under natural conditions. Selection processes were demonstrated, either pre-ingestive or post-ingestive. As a consequence, all algal groups potentially available to the bivalve were consumed different. The ecological implications of this selective feeding behaviour might be considered, regarding the carrying capacity of the Takapoto Atoll lagoon for pearl oyster farming and the long-term evolution of the phytoplankton composition.

Acknowledgements. Research was carried out as part of the 'Programme Général de Recherche sur la Nacre, deuxième phase' (PGRN2) (General Research Program on Pearl-Oyster, second phase), with financial support of the Ministry for Education, Research and Technology, of the Ministry for Overseas, and of the Government of French Polynesia. We express our gratitude to the Director of the Service des Ressources Marines in Takapoto Atoll, G. Haumani, and his team for efficient assistance in the field. We also thank S. Robert for the considerable support in dive sampling and Pr. C. Payri for laboratory facilities. We would thank especially Dr S. Pouvreau for his valuable comments during the writing of this article and the reviewers for their useful comments.

\section{LITERATURE CITED}

Bacher C (1989) Capacité trophique du Bassin de MarennesOléron: couplage d'un modèle de transport particulaire et d'un modèle de croissance de l'huître Crassostrea gigas. Aquat Liv Resour 2:199-214

Baker SM, Levington JS, Kurdziel JP, Shumway SE (1998) Selective feeding and biodeposition by zebra mussels and their relation to changes in phytoplankton composition and seston load. J Shellfish Res 17:1207-1213

Bayne BL, Hawkins AJS, Navarro E (1987) Feeding and digestion by the mussel Mytilus edulis L. (Bivalvia: Mollusca) in mixtures of silt and algal cells at low concentrations. J Exp Mar Biol Ecol 111:1-22

Bidigare RR (1989) Photosynthetic pigment composition of the brown tide alga: unique chlorophyll and carotenoid derivatives. In: Cosper E, Carpenter EJ, Bricelj M (eds) Novel phytoplankton blooms. Coastal and estuarine studies. Springer-Verlag, Berlin, p 57-75

Bidigare RR (1991) Analysis of algal chlorophylls and carotenoids. In: Hurd DC and Spencer DW (eds) Marine particles: analysis and characterisation. Geophysical monograph, American Geophysical Union, Washington, p 119-123

Bidigare RR, Kennicutt MC, Ondrusek ME, Keller MD, Guillard (1990) Novel chlorophyll-related compounds in marine phytoplankton: distributions and geochemical implications. Energy \& Fuels 4:653-657

Björnland T, Tangen K (1979) Pigmentation and morphology of a marine Gyrodinium (Dinophyceae) with a major carotenoid different from peridinin and fucoxanthin. J Phycol 15:457-463

Bougrier S, Hawkins AJS, Héral M (1997) Preingestive selection of different microaigal mixtures in Crassostrea gigas and Mytilus edulis, analysed by flow cytometry. Aquaculture 150:123-134

Buestel D, Pouvreau S (2000) La matière particulaire des eaux du lagon de Takapoto: nourriture potentielle pour les élevages d'huîtres perlières. Oceanol Acta 23:193-210

Buffan-Dubau E, de Wit R, Castel J (1996) Feeding selectivity of the harpacticoid copepod Canuella perplexa in benthic muddy environments demonstrated by HPLC analyses of chlorin and carotenoid pigments. Mar Ecol Prog Ser 137: 71-82

Buma AGJ, Bano N, Veldhuis MJW, Kraay GW (1991) Com- 
parison of the pigmentation of two strains of the prymnesiophyte Phaeocystis sp. Neth J Sea Res 27:173-182

Burkill PH, Mantoura RFC, Llewellyn CA, Owens NJP (1987) Microzooplankton grazing and selectivity of phytoplankton in coastal waters. Mar Biol 93:581-590

Bustillos-Guzmán J, Claustre H, Marty JC (1995) Specific phytoplankton signatures and their relationship to hydrographic conditions in the coastal northwestern Mediterranean Sea. Mar Ecol Prog Ser 124:247-258

Campbell DE, Newell CR (1998) MUSMOD, a production model for bottom culture of the blue mussel, Mytilus edulis L. J Exp Mar Biol Ecol 219:171-203

Charpy L (1996) Phytoplankton biomass and production in two Tuamotu atoll lagoons (French Polynesia). Mar Ecol Prog Ser 145:133-142

Charpy L, Blanchot J (1996) Prochlorococcus contribution to phytoplankton biomass and production of Takapoto atoll (Tuamotu archipelago). CR Acad Sci Paris Série 111 319: 131-137

Charpy L, Blanchot J (1998) Photosynthetic picoplankton in French Polynesian atoll lagoons: estimation of taxa contribution to biomass and production by flow cytometry. Mar Ecol Prog Ser 162:57-70

Charpy L, Blanchot J, Lo L (1992) Contribution des cyanobactéries (Synechococcus spp.) à la production primaire d'un atoll fermé (Takapoto, Tuamotu, Polynésie française). CR Acad Sci Paris Série III 314:395-401

Charpy L, Dufour P, Garcia N (1997) Particulate organic matter in sixteen Tuamotu atoll lagoons (French Polynesia). Mar Ecol Prog Ser 151:55-65

Chellam A (1983) Study on the stomach contents of pearl oyster Pinctada fucata (Gould) with reference to the inclusion of bivalve eggs and larvae. Proc Symp Coast Aquacult 2: 604-607

Claustre H, Kerhervé P, Marty JC, Prieur L, Videau C. Hecq JC (1994) Phytoplankton dynamics with a geostrophic front: ecological and biogeochemical implications. J Mar Res 52:711-742

Dame RF (1993) The role of bivalve filter feeder material fluxes in estuarine ecosystems. In: Dame RF (ed) Bivalve filter feeders in estuarine and coastal ecosystem processes. Springer-Verlag, Berlin, p 245-270

Dupuy C, Le Gall S, Hartmann HJ, Bréret M (1999) Retention of ciliates and flagellates by the oyster Crassostrea gigas in French Atlantic coastal ponds: protists as a trophic link between bacterioplankton and benthic suspension-feeders. Mar Ecol Prog Ser 171:165-175

Gaines G, Elbrächter M (1987) Heterotrophic nutrition. In: Taylor FJR (ed) The biology of dinoflagellates. Blackwell Scientific Publications, London, Bot Monogr 21:224-268

Gaines G, Taylor FJR (1984) Extracellular digestion in marine dinoflagellates. J Plankton Res 6(6):1057-1067

Garrido JL, Zapata M (1998) Detection of new pigments from Emiliania huxleyi (prymnesiophyceae) by high-performance liquid chromatography, liquid chromatographymass spectrometry, visible spectroscopy, and fast atom bombardment mass spectometry. J Phycol 34:70-78

Gerritsen J, Holland AF, Irvine DE (1994) Suspension-feeding bivalves and the fate of primary production: an estuarine model applied to Chesapeake Bay. Estuaries 17:403-416

Gieskes WWC, Kraay (1983) Dominance of Cryptophyceae during the phytoplankton spring bloom in the central North Sea detected by HPLC analysis of pigments. Mar Biol 75:179-185

Gieskes WWC, Kraay GW, Nontji A, Setiapermana D, Sutomo (1988) Monsoonal alternation of a mixed and layered structure in the phytoplankton of the euphotic zone of the
Banda Sea (Indonesia): a mathematical analysis of algal pigment fingerprints. Neth J Sea Res 22:123-137

Goericke R, Montoya JP (1998) Estimating the contribution of microalgal taxa to chlorophyll $a$ in the field-variations of pigment ratios under nutrient- and light- limited growth. Mar Ecol Prog Ser 169:97-112

Grant $J$ (1996) The relationship of bioenergetics and the environment to the field growth of cultured bivalves. J Exp Mar Biol Ecol 200:239-256

Grant J, Bacher C (1998) Comparative models of mussel bioenergetics and their validation at field culture sites. J Exp Mar Biol Ecol 219:21-44

Hager A, Stransky H (1970) Das Carotinoidmuster und die Verbreitung des lichtinduzierten Xanthophyllcyclus in verschiedenen Algenklassen-III Grünalgen. Archiv Mikrobiol 72:68-83

Hallegraeff GM, Jeffrey SW (1984) Tropical phytoplankton species and pigments of continental shelf waters of North and North-West Australia. Mar Ecol Prog Ser 20:59-74

Hawkins AJS, Bayne BL, Mantoura RFC, Llewellyn CA (1986) Chlorophyll degradation and absorption throughout the digestive system of the blue mussel Mytilus edulis L. J Exp Mar Biol Ecol 96:213-223

Hawkins AJS, Smith RFM, Tan SH, Yasin ZB (1998) Suspension-feeding behaviour in tropical bivalve molluscs: Perna viridis, Crassostrea belcheri, Crassostrea iradelei, Saccostrea cucculata and Pinctada margarifera. Mar Ecol Prog Ser 166:173-185

Herman PMJ (1993) A set of models to investigate the role of benthic suspension feeders in estuarine ecosystems. In: Dame RF (ed) Bivalve filter feeders in estuarine and coastal ecosystem processes. Springer-Verlag, Berlin, p 421-454

Hooks CE, Bidigare RR, Keller MD, Guillard RRL (1988) Coccoid eukaryotic marine ultraplankters with four different HPLC pigment signatures. J Phycol 24:571-580

Jeffrey SW, Wright SW (1994) Photosynthetic pigments in the Prymnesiophyceae. In: Green JC, Leadbeater BSC (eds) The Haptophytes algae. Clarendon Press, Oxford, p 111-132

Jeffrey SW, Sielicki M, Haxo FT (1975) Chloroplast pigment patterns in dinoflagellates. J Phycol 11:374-384

Kana TM, Glibert PM, Goericke R, Welschmeyer NA (1988) Zeaxanthin and $\beta$-carotene in Synechococcus WH7803 respond differently to irradiance. Limnol Oceanogr 33: 1623-1627

Kautsky N, Evans S (1987) Role of biodeposition by Mytilus edulis in the circulation of matter and nutrients in a Baltic coastal ecosystem. Mar Ecol Prog Ser 38:201-212

Kleppel GS, Pieper RE (1984) Phytoplankton pigments in the gut contents of planktonic copepods from coastal waters off southern California. Mar Biol 78:193-198

Kraay GW, Zapata M, Veldhuis MJ (1992) Separation of chlorophylls $c_{1}, c_{2}$ and $c_{3}$ of marine phytoplankton by reversed-phase-C18-high-performance liquid chromatography. J Phycol 28:708-712

Le Gall S, Bel Hassen M, Le Gall P (1997) Ingestion of a bacterivorous ciliate by the oyster Crassostrea gigas: protozoa as a trophic link between picoplankton and benthic suspension-feeders. Mar Ecol Prog Ser 152:301-306

Lessard EJ, Swift E (1985) Species-specific grazing rates of heterotrophic dinoflagellates in oceanic waters, measured with a dual-label radioisotope technique. Mar Biol 87 : 289-296

Letelier RM, Bídigare RR, Hebel DV, Ondrusek M, Winn CD, Karl DM (1993) Temporal variability of phytoplankton community structure based on pigment analysis. Limnol Oceanogr 38:1420-1437 
Mackey MD, Mackey DJ, Higgins HW, Wright SW (1996) CHEMTAX - a program for estimating class abundances from chemical markers: application to HPLC measurements of phytoplankton. Mar Ecol Prog Ser 144:265-283

Makarewicz JC, Lewis TW, Bertram P (1999) Phytoplankton composition and biomass in the offshore waters of Lake Erie: pre- and post-Dreissena introduction (1983-1993) J Great Lakes Res 25:135-148

Meyer-Harms B, Von Bodungen B (1997) Taxon-specific ingestion rates of natural phytoplankton by calanoid copepods in an estuarine environment (Pomeranian Bight, Baltic Sea) determined by cell counts and HPLC analyses of marker pigments. Mar Ecol Prog Ser 153:181-190

Meyer-Harms B, Irigoien X, Head R, Harris R (1999) Selective feeding on natural phytoplankton by Calanus finmarchicus before, during, and after the 1997 spring bloom in the Norwegian Sea. Limnol Oceanogr 44:154-165

Nasr DH (1984) Feeding and growth of the pearl oyster Pinctada margaritifera (L.) in Dongonab Bay, Red Sea. Hydrobiol 110:241-245

Nelson JR (1989) Phytoplankton pigments in macrozooplankton faeces: variability in carotenoid alterations. Mar Ecol Prog Ser 52:129-144

Nelson JR, Wakeham SG (1989) A phytol-substituted chlorophyll c from Emiliania huxleyi (Prymnesiophyceae). J Phycol 25:761-766

Newell CR, Shumway SE, Cucci TL, Selvin R (1989) The effects of natural seston particle size and type on feeding rates, feeding selectivity and food resource availability for the mussel Mytilus edulis L., 1758 at bottom culture sites in Maine. J Shellfish Res 8:187-196

Niquil N, Jackson GA, Legendre L, Delesalle B (1998) Inverse model analysis of the planktonic food web of Takapoto Atoll (French Polynesia). Mar Ecol Prog Ser 165:17-29

Numagushi K (1985) Studies on the phaeophytin contained in the digestive diverticula of pearl oyster, Pinctada fucata martensii, as index of feeding of phytoplantkon. Bull Natl Res Inst Aquacult 7:91-96

Pastoureaud A, Héral M, Prou J, Razet D, Russu P (1996) Particle selection in the oyster Crassostrea gigas (Thunberg) studied by pigment HPLC analysis under natural food conditions. Oceanol Acta 19:79-88

Porter KG (1973) Selective grazing and differential digestion of algae by zooplankton. Nature 244:179-180

Pouvseau S, Jonquières G, Buestel D (1999) Filtration by pearl oyster, Pinctada margaritifera, under conditions of low seston load and small particle size in a tropical lagoon habitat. Aquaculture 176:295-314

Pouvseau S, Bodoy A, Buestel D (2000a) In situ suspension feeding behaviour of the pearl oyster, Pinctada margaritifera: combined effects of body size and weather-related seston composition. Aquaculture 181:91-113

Pouvreau S, Bacher C, Héral M (2000b) Ecophysiological model of growth and reproduction of the black pearl oyster, Pinctada margaritifera, potential applications for pearl farming in French Polynesia. Aquaculture 186: $117-144$

Raillard O, Menesguen A (1994) An ecosystem box model for estimating the carrying capacity of a macrotidal shellfish system. Mar Ecol Prog Ser 115:117-130

Repeta DJ, Gagosian RB (1987) Carotenoid diagenesis in recent marine sediments. I. The Peru continental shelf $\left(15^{\circ} \mathrm{S}, 75^{\circ} \mathrm{W}\right)$. Geochim Cosmochim Acta 51:1001-1009

Rheault RB, Rice MA (1996) Food-limited growth and condition index in the eastern oyster, Crassostrea virginica (Gemlin 1791), and the bay scallop, Argopecten irradians (Lamark 1819). J Shellfish Res 15:271-283
Rougerie F (1979) Caractéristiques générales du milieu liquide lagonaire de l'atoll de Takapoto. J Soc Océanistes 35(62):35-45

Sakka A, Legendre L, Gosselin M, LeBlanc B, Delesalle B, Price NM (1999) Nitrate, phosphate, and iron limitation of phytoplankton assemblage in the lagoon of Takapoto Atoll (Tuamotu Archipelago, french Polynesia). Aquat Microb Ecol 19:149-161

Salvat B (1976) Un programme interdisciplinaire sur les écosystèmes insulaires en Polynésie française. Cah Pac 19: 397-406

Schlüter L, Havskum H (1997) Phytoplankton pigments in relation to carbon content in phytoplankton communities. Mar Ecol Prog Ser 155:55-65

Shumway SE, Cucci TL, Newell RC, Yentsch CM (1985) Particle selection, ingestion, and absorption in filter-feeding bivalves. J Exp Mar Biol Ecol 91:77-92

Simon N, Barlow RG, Marie D, Partensky F, Vaulot D (1994) Characterization of oceanic photosynthetic picoeukaryotes by flow cytometer. J Phycol 30:922-935

Smaal AC, Prins TC (1993) The uptake of organic matter and the release of inorganic nutrients by bivalve suspension feeder beds. In: Dame RF (ed) Bivalve filter feeders in estuarine and coastal ecosystem processes. Springer-Verlag, Berlin, p 271-298

Sournia A, Ricard M (1976) Données sur l'hydrologie et la productivité d'un lagon d'atoll fermé (Takapoto, Tuamotu). Vie Milieu 26:243-279

Stewart AJ, Wetzel RG (1986) Cryptophytes and other microflagellates as couplers in planktonic community dynamics. Arch Hydrobiol 106(1):1-19

Stoecker DK, Li A, Coats DW, Gustafson DE, Nannen MK (1997) Mixotrophy in the dinoflagellate Prorocentrum minimum. Mar Ecol Prog Ser 152:1-12

Swalding KM, Marcus NM (1994) Selectivity in the natural diets of Acartia tonsa Dana (Copepoda: Calanoida): comparison of juveniles and adults. J Exp Mar Biol Ecol 181: 91-103

Tester PA, Geesey ME, Guo C, Paerl HW, Millie DF (1995) Evaluating phytoplankton dynamics in the Newport River estuary (North Carolina, USA) by HPLC-derived pigment profiles. Mar Ecol Prog Ser 124:237-245

Utermöhl $\mathrm{H}$ (1958) Zur Vervollkommung der qualitativen Phytoplankton-Methodik. Mitt Int Theor Angew Limnol 9: 1-38

van den Hoek C (1995) Algae: an introduction to phycology Cambridge University Press, Cambridge

Vaulot D, Birrien JL, Marie D, Casotti R, Veldhuis MJW Kraay GW, Chrétiennot-Dinet MJ (1994) Morphology, ploidy, pigment composition and genome size of cultured strains of Phaeocystis (Prymnesiophyceae). J Phycol 30: 1022-1035

Vesk M, Jeffrey SW (1977) Effect of blue-green light on photosynthetic pigments and chloroplast structure in unicellular marine algae from six classes. J Phycol 13:280-288

Ward JE, Levinton JS, Shumway SE, Cuccci T (1998) Particle sorting in bivalves: in vivo determination of the pallial organs of selection. Mar Biol 131:283-292

Wilhelm C, Rudolph I, Renner W (1991) A quantitative method based on HPLC-aided pigment analysis to monitor structure and dynamics of the phytoplankton assemblage - a study from Lake Meerfelder Maar (Eifel, Germany). Arch Hydrobiol 123:21-35

Wright SW, Jeffrey SW (1987) Fucoxanthin pigment markers of marine phytoplankton analysed by HPLC and HPTLC. Mar Ecol Prog Ser 38:259-266

Wright SW, Jeffrey SW, Mantoura RFC, Llewellyn CA, Bjørn- 
land $T$, Repeta D, Welschmeyer N (1991) Improved HPLC method for the analysis of chlorophylls and carotenoids from marine phytoplankton. Mar Ecol Prog Ser 77:183-196

Wright SW, Thomas DP, Marchant HJ, Higgins HW, Mackey MD, Mackey DJ (1996) Analysis of phytoplankton of the Australian sector of the Southern Ocean: comparisons of microscopy and size frequency data with interpretations of pigment HPLC data using the 'CHEMTAX' matrix factorisation program. Mar Ecol Prog Ser 144:285-298

Yukihira H, Klumpp DW, Lucas JS (1998a) Effects of body size on suspension feeding and energy budgets of the pearl oysters Pinctada margaritifera and P. maxima. Mar Ecol Prog Ser 170:119-130

Yukihira H, Klumpp DW, Lucas JS (1998b) Comparative effects of microalgal species and food concentration on sus-

Editorial responsibility: Otto Kinne (Editor),

Oldendorf/Luhe, Germany pension feeding and energy budgets of the pearl oysters Pinctada margaritifera and $P$. maxima (Bivalvia: Pteriidae). Mar Ecol Prog Ser 171:71-84

Yukihira H, Klumpp DW, Lucas JS (1999) Feeding adaptations of the pearl oysters Pinctada margaritifera and $P$. maxima to variations in natural particulates. Mar Ecol Prog Ser 182:161-173

Zanini JM (1997) Méthode d'estimation du stock naturel de nacres - Pinctada margaritifera-de lagons d'atoll, à travers l'exemple des lagons de Marutea Sud et de Takapoto (Polynésie française). Rapport EPHE-EVAAM. RA 65. Tahiti

Zapata M, Garrido JL (1997) Occurrence of phytylated chlorophyll $c$ in Isochrysis galbana and Isochrysis sp. (clone TISO) (Prymnesiophycaea). J Phycol 33:209-214

Submitted: July 26, 1999, Accepted: September 10, 1999 Proofs received from author(s): May 23, 2000 